\title{
The Use of Opuntia ficus-indica Mucilage and Aloe arborescens as Edible Coatings to Improve the Physical, Chemical, and Microbiological Properties of 'Hayward' Kiwifruit Slices
}

\author{
Giuseppe Sortino (D), Paolo Inglese (D), Vittorio Farina (D, Roberta Passafiume (D) and Alessio Allegra *
}

check for updates

Citation: Sortino, G.; Inglese, P.; Farina, V.; Passafiume, R.; Allegra, A. The Use of Opuntia ficus-indica Mucilage and Aloe arborescens as Edible Coatings to Improve the Physical, Chemical, and Microbiological Properties of 'Hayward' Kiwifruit Slices. Horticulturae 2022, 8, 219.

https: / /doi.org/10.3390/ horticulturae8030219

Academic Editors: Yang Bi, Yongcai Li and Di Gong

Received: 4 February 2022 Accepted: 28 February 2022 Published: 2 March 2022

Publisher's Note: MDPI stays neutral with regard to jurisdictional claims in published maps and institutional affiliations.

Copyright: (C) 2022 by the authors. Licensee MDPI, Basel, Switzerland. This article is an open access article distributed under the terms and conditions of the Creative Commons Attribution (CC BY) license (https:/ / creativecommons.org/licenses/by/ $4.0 /)$.
Department of Agricultural, Food and Forest Sciences, Università degli Studi di Palermo, Edificio 4, Ingresso H, 90128 Palermo, Italy; giuseppe.sortino@unipa.it (G.S.); paolo.inglese@unipa.it (P.I.); vittorio.farina@unipa.it (V.F.); roberta.passafiume@unipa.it (R.P.)

* Correspondence: alessio.allegra@unipa.it; Tel.: +39-09123861234

\begin{abstract}
Edible coatings (EC) with mucilage of Opuntia ficus-indica or Aloe arborescens are promising to extend the shelf life of fresh-cut fruit products by reducing weight loss and microbial spoilage. In this work, fresh-cut kiwifruits (cv. Hayward) were coated in solutions with mucilage extracted from Opuntia ficus-indica (MC) and A. arborescens (AL). We used three alternative treatments with AL or $\mathrm{MC}, \mathrm{MC}+\mathrm{AL}$, and with distilled water as control, and stored in passive atmosphere at $5^{\circ} \mathrm{C}$ for $3,5,7$, and $9 \mathrm{~d}$, respectively. For all treatments at each storage period, firmness, weight loss, color, visual quality score, respiration rate, pectin content, and microbiological characteristics were observed. The treatments with mucilage and $A$. arborescens applied on fresh-cut kiwi slices showed different significant effects until 9 days of storage, in terms of firmness and total pectin. Microbial spoilage analysis revealed the beneficial effects of this strategy after $3 \mathrm{~d}$, particularly in terms of bacteria and yeast. A. arborescens provided a reduction of microbial activity, probably due to the higher quantity of aloin if related to Aloe species. Furthermore, the treatment with MC and AL increased the total pectin content, showing positive effects in terms weight loss and firmness. The results showed that the $\mathrm{MC}+\mathrm{AL}$ treatment improved the visual score of fresh-cut kiwi fruit until $7 \mathrm{~d}$ of storage.
\end{abstract}

Keywords: Actinidia deliciosa; pectin contents; fresh-cut; post-harvest; bio-based films; visual color

\section{Introduction}

Kiwifruit (Actinidia spp.) is a typical climacteric fruit that, after harvest, goes through three distinct softening phases that are temporally well separated. Pectin retained in the cell wall starts to "soften" during ripening; this process clearly precedes both pectin solubilization and depolymerization (Phase 1) [1].

The degradation of solubilized pectin and loss of middle lamellae in kiwifruit (Phase 2) are processes initiated in the second softening phase, with a peak in the last softening phase, where cell wall disintegration is completed (Phase 3) [1]. After harvest, kiwifruits can be stored for a long period and sold for fresh consumption or for processing as fresh-cut. The peeling and slicing involved in minimal fruit processing can cause physical damages, and an increase of polyphenoxidase and peroxidase begins browning in the flesh. In fresh-cut fruit, the rapid softening and deterioration likely involve membrane and cell wall catabolism, accelerated or otherwise altered in response to physical wounding [2].

In recent years, limited research works have been carried out on applying various kinds of natural edible coatings to extend fresh-cut kiwifruit during storage. The use of edible coatings could be an efficient alternative to the chemical treatments applied to preserve fresh-cut kiwifruit. Opuntia ficus-indica (OFI) mucilage, A. vera, and A. arborescen coatings reduce physiological disorders and gas exchange $[3,4]$. Moreover, these coatings can maintain total soluble solids, a higher concentration of total phenols and ascorbic acid, and a better antioxidant activity when compared to the control [5-7]. The most 
studied gel from any Aloe spp. has been $A$. vera or $A$. arborescens, where the gel is found in a clear internal zone located between the abaxial and adaxial mesophyll. The chemical composition of the aloe species gel is very complex, composed mainly of polysaccarides and soluble sugars, followed by proteins; most of these are enzymes, amino acids, and vitamins [8]. Zapata et al. [9] showed that $A$. arborescens gel had more aloin concentration, total phenolics, total antioxidant activity (hydrophilic and lipophilic fractions), and a low level of putrescine and spermidine than $A$. vera gel content. However, the use of $A$. arborescens showed overall inhibitions of fungal growth on inoculations in vitro test while the use of OFI mucilage did not show a positive effect on concentration of pseudomonads and yeasts during storage of breba fig fruit [10]. OFI mucilage is present in cladodes, in the Golgi apparatus, and the mucilage synthesis probably takes place in it and in the vesicles derived from it [11]. These polysaccharides swell when dissolved in water, or in some cases, form colloidal and very viscous suspensions or jellied masses [12]. In particular, OFI mucilage has complex polymeric substances of a carbohydrate nature; a highly branched structure [13]; and is composed of arabinose, galactose, rhamnose, xylose and galacturonic acid [14]. The use of a natural edible coating could replace calcium-based treatments and compounds made from different fermentation or polymerization reactions (e.g., HPMC, Xanthan gum, etc.). OFI mucilage and $A$. vera coatings have been previously studied by Allegra [14] and Benitez [3], regarding the maintenance of quality in kiwifruit slices during storage. However, those studies showed that non-combined treatments have not improved the physical and microbiological qualities of fresh-cut kiwi during storage. Benitez showed that, with kiwi slices, coated and uncoated samples were given similar scores during storage, except in the bitterness attributes.

The objective of the present work was to evaluate the efficacy of $O$. ficus-indica coatings with $A$. arborescens ( $2 \%$ ) in prolonging the shelf life of kiwifruit slices. We focused our study on the effects of OFI mucilage with $A$. arborescens on the visual quality score, firmness, and microbial load of minimally processed kiwifruit slices, during 9 days of storage.

\section{Materials and Methods}

\subsection{Fruits and Preparation of the Edible Coating}

'Hayward' kiwifruits (Actinia deliciosa) were purchased from a supermarket belonging to a large, very well-known organized distributor in Italy, which provides medium-high quality products (Conad, Palermo, Italy). Kiwifruits were selected based on their firmness $(49 \mathrm{~N} \pm 2.2)$ and soluble solid total $\left(12.5^{\circ}\right.$ Brix \pm 0.2$)$ stored in air at $5 \pm 0.5^{\circ} \mathrm{C}(\mathrm{RH}=85 \%)$ for $24 \mathrm{~h}$. After storage, the fruits were dipped in chlorinated water (100 ppm of free chlorine) for $6 \mathrm{~min}$. Damaged fruits (bruised or showing other physical decays) were removed, and a total of 400 fruits with an average firmness of $48.2 \pm 3.5 \mathrm{~N}$ and weight of $100 \pm 4.2 \mathrm{~g}$ were processed.

Cactus pear (O. ficus-indica (L.) Mill.) cladodes were collected from an experimental field near Roccapalumba $\left(37^{\circ} 48^{\prime} \mathrm{N} ; 13^{\circ} 38^{\prime} \mathrm{E} ; 350 \mathrm{~m}\right.$ asl), western Sicily, Italy. Promptly after harvest, cladodes were transported to the post-harvest laboratory of the University of Palermo and were cut and cubed $\left(2 \mathrm{~cm}^{3}\right)$. Samples were homogenized $(20 \% w / v)$ in distilled water with water ratio 1:1.5. The solution was maintained at $40{ }^{\circ} \mathrm{C}$ for $90 \mathrm{~min}$ and centrifuged (model CS6R) at $3000 \mathrm{rpm} \times 20 \mathrm{~min}$. The supernatant was boiled to halve the initial volume, and ethanol at $99 \%$ was added in ratio 1:2, in order to reduce the amount of alcohol used in the precipitation [15]. Afterwards, the solution was stored at $4 \pm 1{ }^{\circ} \mathrm{C}$ for $48 \mathrm{~h}$ to allow a better aggregation of the mucilage. The last phase involved the elimination of the supernatant and the soaking of the pure mucilage.

Matured leaves of the $A$. arborescens plant were harvested at the experimental field of the University of Palermo (Italy). A. arborescens gel was prepared from $1 \mathrm{~kg}$ of leaves taken from 10-year-old plants. The leaves were cleaned externally with a knife, removing the margin, and were then cut lengthwise. The parenchyma (from which the gel is obtained) was separated from the epidermis. The gelatinous parenchyma was homogenized with Ultra-Turrax (Ultra-Turax T25, Janke and Kunkle, IKa Labortechnik, Breisgau, Germany) 
for $5 \mathrm{~min}$ at 24,500 rpm, thus obtaining a mucilaginous gel, and was subsequently filtered to eliminate the fibrous portion [16].

\subsection{Fruit Processing}

Kiwifruits were peeled manually and cut into slices with a semiautomatic machine. Slices were $2.2 \pm 0.3 \mathrm{~cm}$ thick and $5.4 \pm 1.1 \mathrm{~cm}$ diameter, characterized by the Hunter's parameters $\mathrm{L}^{*}=66.6 \pm 2.4, \mathrm{a}^{*}=7.8 \pm 1.3$, and $\mathrm{b}^{*}=25.4 \pm 2.1$, with a total solid soluble content (SST) of $12.9 \pm 2.2^{\circ}$ Brix and titratable acidity (TA) of $1.5 \pm 0.4\left(\mathrm{~g} \mathrm{~L}^{-1}\right)$. Fresh-cut slices were dipped in the coating solution for $60 \mathrm{~s}$; the excess coating was drained, and the coated slices were dried in a forced-air dryer $\left(20^{\circ} \mathrm{C}\right)$ for $10 \mathrm{~min}$.

The coating treatment consisted of: (a) $30 \mathrm{~g}$ of pure mucilage extract, $500 \mathrm{~mL}$ distilled water with $2 \%$ of $A$. arborescens and $50 \mathrm{~mL}$ glycerol as a plasticizer (MC+AL); (b) $30 \mathrm{~g}$ of mucilage extract, $500 \mathrm{~mL}$ distilled water, $50 \mathrm{~mL}$ glycerol (MC); (c) $500 \mathrm{~mL}$ distilled water with $2 \%$ of $A$. arborescens and $50 \mathrm{~mL}$ glycerol as a plasticizer. The control trial (CTR) was set up by sliced fruits dipped in distilled water. Approximately $100 \mathrm{~g} \pm 0.8$ of kiwifruit slices were packed in polyethylene terephthalate (PET) packages and sealed with a composite film (PP-PET, $64 \mu \mathrm{m}, \mathrm{O}_{2}$ permeability $=5.30 \times 10^{-8} \mu \mathrm{L} \mathrm{m}^{-2} \mathrm{~s}^{-1} \mathrm{~Pa}^{-1}$ ). Packages were stored at $5{ }^{\circ} \mathrm{C}$ and $90 \%$ relative humidity (RH) for $9 \mathrm{~d}$. Physico-chemical and microbiological quality parameters were analyzed on six slices used as single replicates ( 4 treatments $\times 5$ time of storage $\times 6$ replicates $=120$ box), at the beginning of the experiment (after coating/dipping $=$ day 0 ) and at 3, 5, 7, and $9 \mathrm{~d}$ after storage.

\subsection{Firmness}

Firmness was evaluated by a puncture test on kiwifruit slice flesh using a TA-XT Plus texture analyzer (Stable Micro Systems, Surrey, England). Firmness measurements were taken as the medium force value obtained during the test by a stainless steel probe with $4 \mathrm{~mm}$ diameter penetrating inside the fruit for $4 \mathrm{~mm}$, at $1 \mathrm{~mm} / \mathrm{s}$. Average values were calculated from the results of at least six measurements in different slices for each sample. Measures were taken in the fruit outer pericarp (green flesh), where the fast rate of softening compromised fruit quality.

\subsection{Weight Loss (\%)}

The weight of individual bags was recorded immediately after the treatment (day 0 ) and at the different sampling times $(3,5,7$, and $9 \mathrm{~d}$ during storage). Weight loss was expressed as the percentage reduction with respect to initial time, using the following equation:

$\%$ Weight loss $=[($ Initial fruit bags weight - Final fruit bags weight $) \times 100] /$ Initial fruit bags weight

\subsection{Total Soluble Solids Content and Titratable Acidity}

Soluble solids total concentration was determined with a hand-held refractometer, and $\mathrm{pH}$ was determined by a $\mathrm{pH}$ meter. Titratable acidity (expressed as $\%$ citric acid) was determined by titration of $10 \mathrm{~mL}$ of juice with $0.1 \mathrm{M} \mathrm{NaOH}$ to an endpoint of $\mathrm{pH} 8.1$ [3].

\subsection{Visual Appearance Score}

To measure the effect of cold storage on kiwifruit sensory traits at each storage time $(0$, $3,5,7$, and $9 \mathrm{~d}$ ), six slices, used as single replicates for treatment $(\mathrm{MC}+\mathrm{AL}, \mathrm{MC}, \mathrm{AL}$, and CTR), were scored by each of a six-judge trained panel, who generated a list of descriptors in a few preliminary meetings. All panelists participated in $10 \mathrm{~d}$ of training and $6 \mathrm{~d}$ of tasting, lasting for a total of 4 weeks. Visual appearance was focused on color, visible structural integrity, and visual appearance [17]. The different descriptors were quantified using a subjective $5 \mathrm{pt}$. scoring scale with $5=$ very good, $4=$ good, $3=$ sufficient (limit of marketability), 2 = poor (limit of usability), and $1=$ very poor (inedible). 


\subsection{Package $\mathrm{O}_{2}$ and $\mathrm{CO}_{2}$ Analysis}

$\mathrm{CO}_{2}$ and $\mathrm{O}_{2}$ levels (Kpa) were measured on each package at the beginning of each experiment and after 3, 5, 7, and $9 \mathrm{~d}$ of storage, using a PBI Dansensor Checkpoint $\mathrm{O}_{2}$ and $\mathrm{CO}_{2}$ analyzer (Topac, Hingham, MS, USA) with zirconium and infrared detectors, respectively.

\subsection{Color}

The superficial color of the kiwifruit slices was determined using a Minolta colorimeter CR-400 model (Minolta Camera, Osaka, Japan) in the CIElab space. The $L^{*}$ (lightness), $\mathrm{a}^{*}$ (greenness $(-)$ to redness $(+)$ ), and $\mathrm{b}^{*}$ (blueness $(-)$ to yellowness $(+)$ ) values were recorded for each treatment at $3,5,7$, and $9 \mathrm{~d}$ [5]. Total color difference $\left(\Delta \mathrm{E}^{*}\right)$ expressed the magnitude of the difference between the initial non-aged color pulp (zero time) and storageaged samples. Total color difference $\left(\Delta \mathrm{E}^{*}\right)$ was calculated according to the following:

$$
\Delta \mathrm{E}^{*}=\left[\left(\Delta \mathrm{L}^{*}\right)^{2}+\left(\Delta \mathrm{a}^{*}\right)^{2}+\left(\Delta \mathrm{b}^{*}\right)^{2}\right]^{1 / 2}
$$

where $\Delta \mathrm{a}^{*}=\mathrm{a}^{*}-\mathrm{a}_{0}{ }^{*}, \Delta \mathrm{b}^{*}=\mathrm{b}^{*}-\mathrm{b}_{0}{ }^{*}, \Delta \mathrm{L}^{*}=\mathrm{L}^{*}-\mathrm{L}_{0}{ }^{*} ; \mathrm{a}_{0}{ }^{*}, \mathrm{~b}_{0}{ }^{*}$, and $\mathrm{L}_{0}{ }^{*}$ are the corresponding blank values of control sample, and $\mathrm{a}_{0}{ }^{*}=-2.00, \mathrm{~b}_{0}{ }^{*}=4.00$, and $\mathrm{L}_{0}{ }^{*}=80.00$, respectively [5]. All data were reported as mean \pm standard error $(\mathrm{SE}, n=6)$.

\subsection{Microbiological Analysis}

Fruit samples and mucilage were microbiologically investigated for total mesophilic microorganisms (TMM) and the undesired (spoilage and/or pathogenic) microbial groups. The fruits $(25 \mathrm{~g})$, A. arborescens $(10 \mathrm{~mL})$, and mucilage $(10 \mathrm{~mL})$ were suspended in Ringer's solution (Sigma-Aldrich, Milan, Italy) with a ratio 1:10 (fruit:diluent), homogenized for 2 min at the highest speed with a stomacher (BagMixer ${ }^{\circledR} 400$, Interscience, Saint Nom, France), and serially diluted. The cell suspensions were inoculated as follows: TMM on plate count agar (PCA), incubated at $30^{\circ} \mathrm{C}$ for $72 \mathrm{~h}$; Pseudomonas on Pseudomonas agar base $(\mathrm{PAB})$, supplemented with $10 \mathrm{mg} / \mathrm{mL}$ cetrimide fucidin, incubated at $20^{\circ} \mathrm{C}$ for $48 \mathrm{~h}$; yeasts on yeast potato dextrose (YPD) agar, incubated at $25^{\circ} \mathrm{C}$ for $48 \mathrm{~h}$. All materials and supplements were purchased from Oxoid (Milan, Italy). Count plates were carried out in duplicate for each trial.

\subsection{Pectin Analysis}

The pectic substances from fruits were extracted according to the methods described by Rouse and Atkins $[18,19]$. Frozen 'Hayward' A. deliciosa were thawed at $4{ }^{\circ} \mathrm{C}$ for $24 \mathrm{~h}$; approximately $20 \mathrm{~g}$ were weighed into a plastic cup and homogenized at low speed with an Ultra-Turrax tissue mixer for $2 \mathrm{~min}$. The tissue sample $(5 \mathrm{~g})$ was weighed into a $50 \mathrm{~mL}$ round-bottom plastic centrifuge tube. Hot $100 \%$ ethanol $(30 \mathrm{~mL})$ was added to the tubes. The samples were stirred thoroughly with a glass rod, heated in a boiling water bath for $10 \mathrm{~min}$, cooled, and centrifuged at 10,000 rpm for $10 \mathrm{~min}$. The alcoholic supernatant was decanted and discarded. The precipitate was extracted with $30 \mathrm{~mL} 100 \%$ ethanol, centrifuged, and the supernatant was discarded. The residue was transferred from the centrifuge tube to a $57 \mathrm{~mm}$ aluminum weighing dish (Fisher Scientific Inc. Italia, Milan, Italy). Samples were dried for $24 \mathrm{~h}$ in a conventional oven at $35^{\circ} \mathrm{C}$, weighed, and ground in a 65 mortar with a pestle. The precipitate from the alcohol solution was designated as alcohol-insoluble solids (AIS).

\subsubsection{Water Soluble Pectin}

Dried alcohol-insoluble solid (AIS) $(80 \mathrm{mg}$ ) was weighed into a $50 \mathrm{~mL}$ centrifuge tube. Distilled water $(20 \mathrm{~mL})$ was added, and samples were stirred with a glass rod for $1 \mathrm{~min}$. Samples were centrifuged at 10,000 rpm for $10 \mathrm{~min}$ and filtered through Whatman No. 1 filter paper to obtain water-soluble pectin (WSP). The extraction procedure was repeated once. The supernatants were collected and combined in a $100 \mathrm{~mL}$ volumetric flask. Distilled water was added to dilute the tube extract solution to volume. 


\subsubsection{Oxalate Soluble Pectin}

The residue was dispersed in $20 \mathrm{~mL}$ of an aqueous solution containing $0.25 \%$ ammonium oxalate and $0.25 \%$ oxalic acid and stirred with a glass rod for $1 \mathrm{~min}$. Samples were refluxed in a boiling water bath for $1 \mathrm{~h}$, centrifuged at 10,000 rpm for $10 \mathrm{~min}$, and filtered through Whatman No. 1 filter paper to obtain oxalate-soluble pectin (OSP). The oxalate extraction was repeated once. Supernatants were collected and diluted to $100 \mathrm{~mL}$ with distilled water in a volumetric flask.

\subsubsection{Total Pectin}

Total pectin (TP) was extracted following the method of Ahmed and Labavitch [20]. Dried AIS (5 mg) was weighed into a $30 \mathrm{~mL}$ beaker containing a magnetic stir bar. Concentrated sulfuric acid $(2 \mathrm{~mL})$ was added to the beaker, and the mixture was swirled gently. The beaker was placed on a stir plate and stirred gently, and $0.5 \mathrm{~mL}$ of distilled water were added dropwise. Stirring continued for $5 \mathrm{~min}$; an additional aliquot of $0.5 \mathrm{~mL}$ distilled water was added dropwise. Stirring continued further for approximately $30 \mathrm{~min}$ until the dissolution of the AIS was complete. The dissolved sample was filtered through glass wool into a $25 \mathrm{~mL}$ volumetric flask. Each beaker was rinsed several times with distilled water, combined in a $25 \mathrm{~mL}$ flask, and diluted to volume. The solution was filtered through glass wool once more before use.

\subsubsection{Non-Extractable Pectin}

The difference between TP and the sum of WSP and OSP was used to determine the amount of non-extractable pectin (NXP), which was the protopectin fraction. TP, WSP, and OSP extractions were completed in duplicate for all samples. All pectin extracts were stored at $5{ }^{\circ} \mathrm{C}$ for $12 \mathrm{~h}$ before analysis.

\subsubsection{Pectin Content Determination}

Pectin extracts contents were analyzed by the m-hydroxydiphenyl method [21]. The extract from each sample $(1 \mathrm{~mL})$ was pipetted into a $16 \times 150 \mathrm{~mm}$ test tube. Sulfuric acid tetraborate solution ( $0.0125 \mathrm{M}$ sodium tetraborate in concentrated sulphuric acid) $(6 \mathrm{~mL})$ was added to each of the tubes in an ice water bath and mixed carefully using a Vortex mixer at moderate speed, with intermittent stopping to assure complete mixing. Duplicate samples were prepared for each pectin measurement with a corresponding blank. Tubes were heated in a boiling water bath for $5 \mathrm{~min}$ and immediately placed in ice water to cool. To duplicate tubes, $0.1 \mathrm{~mL}$ aliquot of $0.15 \% \mathrm{~m}$-hydroxydiphenyl, was added to develop color. To the blank tube, $0.1 \mathrm{~mL} 0.5 \%$ sodium hydroxide was added. All samples and blanks were mixed using the Vortex mixer and allowed to stand for $15 \mathrm{~min}$ at room temperature. The absorbance of the samples following chromogen formation was measured at the wavelength of $520 \mathrm{~nm}$ using a Spectrophotometer. Galacturonic acid was used as a standard. A solution consisting of $1 \mathrm{~mL}$ distilled water, $6 \mathrm{~mL}$ sulfuric acid/tetraborate, and $0.1 \mathrm{~mL} 0.5 \%$ sodium hydroxide was used as reagent blank. The determination of the pectin was carried out according to $\mathrm{Yu}$ et al. [22].

\subsection{Statistical Analysis}

The experimental design consisted of three coating treatments and the untreated control, with observations made at $0,3,5,7$, and $9 \mathrm{~d}$ after coating. Analysis of Variance (ANOVA) to compare collected data was used (Systat 13.0 (Systat Software, Inc. San Jose, CA USA) was used as statistical software). Significant differences $(p \leq 0.05)$ were evaluated using the Tukey's test.

\section{Results and Discussion}

\subsection{Solid Soluble Total (SST), Titratable Acidity (TA), Color and Visual Score}

Kiwifruit slice SST did not change significantly between treatments during storage time, but after $3 \mathrm{~d}$, the sample slices treated with mucilage (MC) showed significant 
differences compared to the other treatments (CTR, AL, MC+AL). The control slices (CTR) and $\mathrm{MC}$ treatment showed an increase of mean values from 12.9 at $14.1{ }^{\circ}$ Brix and 12.9 at $13.9^{\circ}$ Brix, respectively (Table 1 ). This is related to the sharp increase of ethylene and respiration rate [23]. Jordan et al. [24] observed that most of the carbohydrates in kiwifruit at harvest were starch, which was hydrolyzed into sugar during further ripening and may lead to the increase of TSS. Untreated kiwifruit slices showed a sharp, significant $(p \leq 0.05)$ increase in SST, while no significant differences were observed in "MC+AL" and AL treatments during storage time (Table 1). Similar results were obtained by Sicari et al. [25] during conservation of strawberry fruits coated with $A$. arborescens gel. A reverse trend during storage time was observed (Table 2) in terms of values of TA; CTR and AL treatments both showed a significant decrease $(p \leq 0.05)$ from cutting at day 9 , while slices coated with $\mathrm{MC}+\mathrm{AL}$ and $\mathrm{MC}$ showed no significant decrease during storage time. The reduction of acidity content in kiwifruit is related to softening and therefore may be associated with the consumption of organic acids under the mechanism of respiration and gluconeogenesis. Generally, the titratable acid content of most fruits increases or remain unchanged during the ripening process, and decreases only at a very ripe stage [26]. The treatment with $\mathrm{MC}+\mathrm{AL}$ and $\mathrm{MC}$ influenced TA content by maintaining the mean values between 1.6 and $1.4 \%$. In breba fig fruit, the malic acid, glutamic acid, citric acid, pipecolic acid, benzoic acid, malonic acid, pelargonic acid, stearic acid, and linoleic acid were higher in sample coated with OFI mucilage than in control samples analyzed at commercial harvest time [27].

Table 1. Solid soluble total of fruit slices of Actinidia deliciosa (Liang. Ferguson) coated with $O$. ficus-indica (OFI) mucilage (MC), or mucilage + A. arborescens $(\mathrm{MC}+\mathrm{AL})$ or $A$. arborescens (AL) not treated (CTR), just after being coated $(0)$ and at $3,5,7,9 \mathrm{~d}$ of storage at $5{ }^{\circ} \mathrm{C}$. Different lowercase letters indicate significant differences between treatments at each sampling date. Different capital letters indicate significant differences between sampling date for the same treatment. Tukeys' significant test was applied at $p \leq 0.05$. Data are means \pm S.E. $(n=3)$.

\begin{tabular}{ccccc}
\hline \multirow{2}{*}{$\begin{array}{c}\text { Time of Storage } \\
\text { (Days) }\end{array}$} & \multicolumn{4}{c}{ Solid Soluble Total $\left({ }^{\circ}\right.$ Brix) } \\
\cline { 2 - 5 } & CTR & MC & MC+AL & AL \\
\hline 0 days & $12.9 \pm 0.2 \mathrm{~A} \mathrm{nsA}$ & $12.9 \pm 0.2 \mathrm{NS}$ & $12.9 \pm 0.2 \mathrm{~A}$ & $12.9 \pm 0.2 \mathrm{NS}$ \\
3 days & $13.2 \pm 0.2 \mathrm{nsA}$ & $13.1 \pm 0.1$ & $13.3 \pm 0.2 \mathrm{~A}$ & $13.0 \pm 0.3$ \\
5 days & $13.5 \pm 0.2 \mathrm{aA}$ & $13.0 \pm 0.1 \mathrm{~b}$ & $13.5 \pm 0.4 \mathrm{aA}$ & $13.2 \pm 0.4 \mathrm{a}$ \\
7 days & $13.7 \pm 0.4 \mathrm{nsA}$ & $13.3 \pm 0.3$ & $13.5 \pm 0.2 \mathrm{~A}$ & $13.3 \pm 0.2$ \\
9 days & $14.1 \pm 0.1 \mathrm{nsAB}$ & $13.9 \pm 0.4$ & $13.6 \pm 0.5 \mathrm{AB}$ & $13.5 \pm 0.2$ \\
\hline
\end{tabular}

Table 2. Titratable acidity of fruit slices of Actinidia deliciosa (Liang. Ferguson) coated with O. ficusindica (OFI) mucilage (MC), or mucilage + A. arborescens $(\mathrm{MC}+\mathrm{AL}$ ) or $A$. arborescens $(\mathrm{AL})$ not treated (CTR), just after being coated (0) and at $3,5,7,9 \mathrm{~d}$ of storage at $5{ }^{\circ} \mathrm{C}$. Different lowercase letters indicate significant differences between treatments at each sampling date. Different capital letters indicate significant differences between sampling date for the same treatment. Tukeys' significant test was applied at $p \leq 0.05$. Data are means \pm S.E. $(n=3)$.

\begin{tabular}{ccccc}
\hline \multirow{2}{*}{$\begin{array}{c}\text { Time of Storage } \\
\text { (Days) }\end{array}$} & \multicolumn{4}{c}{ Titratable Acidity $\left.\mathbf{g ~ L}^{-\mathbf{1}}\right)$} \\
\cline { 2 - 5 } & $\mathbf{C T R}$ & $\mathbf{M C}$ & $\mathbf{M C}+\mathbf{A L}$ & $\mathbf{A L}$ \\
\hline 0 days & $1.8 \pm 0.2 \mathrm{nsA}$ & $1.8 \pm 0.2 \mathrm{NS}$ & $1.8 \pm 0.2 \mathrm{NS}$ & $1.8 \pm 0.2 \mathrm{~A}$ \\
3 days & $1.5 \pm 0.2 \mathrm{aA}$ & $1.7 \pm 0.3 \mathrm{a}$ & $1.6 \pm 0.2 \mathrm{~b}$ & $1.7 \pm 0.5 \mathrm{bA}$ \\
5 days & $1.3 \pm 0.1 \mathrm{aAB}$ & $1.6 \pm 0.2 \mathrm{~b}$ & $1.6 \pm 0.1 \mathrm{~b}$ & $1.6 \pm 0.3 \mathrm{bA}$ \\
7 days & $1.2 \pm 0.3 \mathrm{aAB}$ & $1.5 \pm 0.1 \mathrm{~b}$ & $1.6 \pm 0.4 \mathrm{~b}$ & $1.5 \pm 0.2 \mathrm{bA}$ \\
9 days & $0.9 \pm 0.6 \mathrm{~B}$ & $1.4 \pm 0.5 \mathrm{~b}$ & $1.4 \pm 0.2 \mathrm{~b}$ & $1.0 \pm 0.3 \mathrm{aB}$ \\
\hline
\end{tabular}

The brightness values $\left(\mathrm{L}^{*}\right)$ showed a significant difference between treatments at all storage time points (Table 3 ). After cutting, $\mathrm{MC}+\mathrm{AL}$ samples showed a slow decrease 
from the $3 \mathrm{rd}$ to the 7 th day, while at the 9 th day there was a significant decrease of $30 \%$ of brightness. The $\mathrm{L}^{*}$ value of untreated kiwifruit slices showed an increase from the 5 th to the 7th day: 58.4 and 70.4, respectively. The development of translucency, as a sign of tissue injury, could be triggered by an excessive in-package accumulation of $\mathrm{CO}_{2}$ [28] or by water loss from the inside to the outside of cut fruit.

Table 3. Color $\mathrm{L}^{*}$ of fruit slices of Actinidia deliciosa (Liang. Ferguson) coated with O. ficus-indica (OFI) mucilage (MC), or mucilage + A arborescens $(\mathrm{MC}+\mathrm{AL})$ or $A$. arborescens (AL) not treated (CTR), just after being coated (0) and at 3, 5, 7, $9 \mathrm{~d}$ of storage at $5{ }^{\circ} \mathrm{C}$. Different lowercase letters indicate significant differences between treatments at each sampling date. Different capital letters indicate significant differences between sampling date for the same treatment. Tukeys' significant test was applied at $p \leq 0.05$. Data are means \pm S.E. $(n=3)$.

\begin{tabular}{ccccc}
\hline \multirow{2}{*}{$\begin{array}{c}\text { Time of Storage } \\
\text { (Days) }\end{array}$} & CTR & MC & MC+AL & AL \\
\cline { 2 - 5 } & $66.6 \pm 2.4 \mathrm{nsA}$ & $66.6 \pm 2.4 \mathrm{nsA}$ & $66.6 \pm 2.4 \mathrm{nsA}$ & $66.6 \pm 2.4 \mathrm{nsA}$ \\
\hline 0 days & $60.3 \pm 1.9 \mathrm{cB}$ & $67.4 \pm 1.9 \mathrm{abA}$ & $68.4 \pm 5.3 \mathrm{aA}$ & $68.2 \pm 2.1 \mathrm{aA}$ \\
3 days & $58.4 \pm 1.9 \mathrm{~dB}$ & $60.1 \pm 2.9 \mathrm{cB}$ & $67.4 \pm 3.2 \mathrm{bA}$ & $69.9 \pm 2.0 \mathrm{aA}$ \\
5 days & $70.4 \pm 2.8 \mathrm{aC}$ & $58.9 \pm 3.4 \mathrm{cC}$ & $67.1 \pm 1.9 \mathrm{bA}$ & $51.4 \pm 5.8 \mathrm{~dB}$ \\
7 days & $51.5 \pm 1.9 \mathrm{bD}$ & $55.2 \pm 5.3 \mathrm{aD}$ & $45.7 \pm 3.7 \mathrm{cB}$ & $52.1 \pm 4.7 \mathrm{bB}$ \\
\hline
\end{tabular}

The color change measured with $\Delta \mathrm{E}$ in slices coated with mucilage $+A$. arborescens $(\mathrm{MC}+\mathrm{AL})$ showed no relevant differences during the first $3 \mathrm{~d}$ of storage compared to other treatments, while after $3 \mathrm{~d}$ the mean values of $\Delta \mathrm{E}$ showed significant differences between CTR, MC, and AL treatments (Table 4). During storage, no significant $(p \leq 0.05)$ changes in slices coated with $\mathrm{MC}+\mathrm{AL}$ were observed; in fact, only after $9 \mathrm{~d}$ was a change loss of $3.5 \%$ seen. A change of color occurred in untreated slices (CTR), showing significant difference between MC and AL.

Table 4. $\Delta \mathrm{E} \%$ of fruit slices of Actinidia deliciosa (Liang. Ferguson) coated with $O$. ficus-indica (OFI) mucilage $(\mathrm{MC})$, or mucilage $+A$. arborescens $(\mathrm{MC}+\mathrm{AL})$ or $A$. arborescens (AL) not treated (CTR), just after being coated $(0)$ and at $3,5,7,9$ days of storage at $5{ }^{\circ} \mathrm{C}$. Different lowercase letters indicate significant differences between treatments at each sampling date. Different capital letters indicate significant differences between sampling date for the same treatment. Tukeys' significant test was applied at $p \leq 0.05$. Data are means \pm S.E. $(n=3)$.

\begin{tabular}{ccccc}
\hline \multirow{2}{*}{$\begin{array}{c}\text { Time of Storage } \\
\text { (Days) }\end{array}$} & CTR & MC & MC+AL & AL \\
\cline { 2 - 5 } & $1.2 \pm 0.3 \mathrm{nsA}$ & $0.8 \pm 0.2 \mathrm{~A}$ & $0.7 \pm 0.2 \mathrm{~A}$ & $1.3 \pm 0.5 \mathrm{~A}$ \\
\hline 3 days & $3.1 \pm 0.4 \mathrm{aB}$ & $1.2 \pm 0.4 \mathrm{bA}$ & $0.9 \pm 0.1 \mathrm{cA}$ & $1.8 \pm 0.4 \mathrm{bA}$ \\
5 days & $4.7 \pm 0.8 \mathrm{aB}$ & $2.2 \pm 0.3 \mathrm{bAB}$ & $1.1 \pm 0 \mathrm{cA}$ & $2.1 \pm 0.4 \mathrm{bA}$ \\
7 days & $7.9 \pm 1.9 \mathrm{aC}$ & $5.2 \pm 1.1 \mathrm{bB}$ & $3.3 \pm 0.9 \mathrm{cB}$ & $5.1 \pm 0.7 \mathrm{bB}$ \\
\hline
\end{tabular}

Kiwifruit slice control showed a continuous and significant $\Delta \mathrm{E}$ increase throughout the storage period $(p \leq 0.05)$ and, at the end of the storage period, showed higher color loss between the coated slices (Table 4 ). Because a $\Delta \mathrm{E}$ value $>4$ is considered perceptible to human eyes (CIE 2004), all differences, between the color at cutting time and the measured one during storage, were visible only after $7 \mathrm{~d}$ of storage.

$\mathrm{MC}+\mathrm{AL}$ and $\mathrm{MC}$ treatments had the best visual appearance scores for all sampling times, while CTR and AL treatments had the fastest decay rates, becoming almost nonmarketable, respectively, after 3 and $5 \mathrm{~d}$ of storage (Figure 1). In term of visual score, kiwifruit slices coated with $\mathrm{MC}+\mathrm{AL}$ were still marketable after $7 \mathrm{~d}$ of storage, with a rapid decline of values similar to MC treatment. 


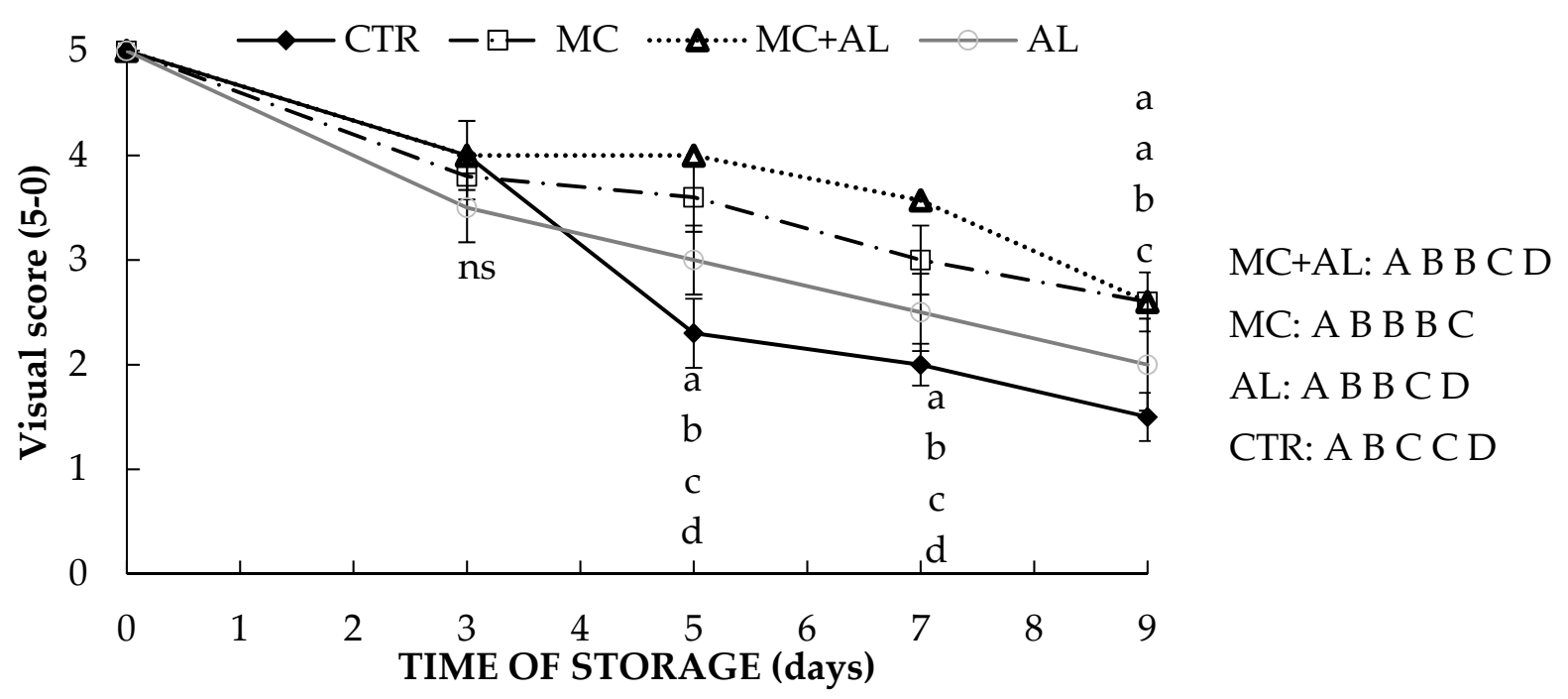

Figure 1. Visual score of fruit slices of Actinidia deliciosa (Liang, Ferguson) coated with O. ficus-indica $(\mathrm{OFI})$ mucilage $(\mathrm{MC})$, or mucilage $+A$. arborescens $(\mathrm{MC}+\mathrm{AL})$ or $A$. arborescens (AL) not treated (CTR), just after being coated (0) and at $3,5,7,9$ days of storage at $5{ }^{\circ} \mathrm{C}$. Different lowercase letters indicate significant differences between treatments at each sampling date. Different capital letters indicate significant differences between sampling date for the same treatment. Tukeys' significant test was applied at $p \leq 0.05$. Data are means \pm S.E. $(n=3)$.

Differences between treatments appeared $3 \mathrm{~d}$ after storage when untreated; CTR slices had the lowest value, while at the same time, no differences occurred between MC+AL and MC coated slices (Figure 1).

\subsection{Firmness, Weight Loss and Pectin Content}

Fruit softening is initiated and sustained by developmental and hormonal signals, and at the biochemical level it involves extensive remodeling and breakdown of the cell wall structure [29] with solubilization and depolymerisation of pectins [30]. The polysaccharide composition of $A$. vera gel [31] and OFI mucilage [14] has proved to be highly effective as a moisture barrier.

In our work, $\mathrm{MC}+\mathrm{AL}$ kiwifruit slices had the highest firmness throughout the storage period (Figure 2). These results can be linked with the pectin total content detected in $\mathrm{MC}+\mathrm{AL}$ samples. Indeed, fresh-cut processing causes the disruption of surface cells and injury stress of underlying tissues. The increases of pectin with OFI mucilage and A. arborescens coating could reduce the increase of membrane permeability and tissue disturbance. Moreover, calcium content into OFI mucilage [32] can maintain cell wall stability and integrity, as well as determining fruit quality [33]. Stabilization of membrane systems and formation of calcium pectates increased the rigidity of the middle lamella and cell walls and retarded polygalacturonase (PG) activity [34]. Composite coatings of polysaccharides could increase the lipid content, which, as a result, could further reduce the weight loss and firmness [35].

During the first $3 \mathrm{~d}$ of storage, there occurred a reduction of firmness from $48.2 \mathrm{~N}$ to 40-37 $\mathrm{N}$ in all treatments, and no significant differences were observed. After $5 \mathrm{~d}$, kiwifruit slices MC+AL and MC treatments showed significant differences $(p \leq 0.05)$ compared to untreated slices (CTR) and AL treatment. However, on the 7th day, the values of sample slices treated with $\mathrm{MC}+\mathrm{AL}$ rapidly declined to values similar to CTR and AL treatment. At the last sampling time (Figure 2), significant differences occurred between MC and CTR, $\mathrm{AL}$, and $\mathrm{MC}+\mathrm{AL}$ treatments, showing, respectively, a firmness loss of 40.2, 54.8, 53.7, and $50.1 \%$ compared to firmness measured after cutting $(48.2 \mathrm{~N})$. 


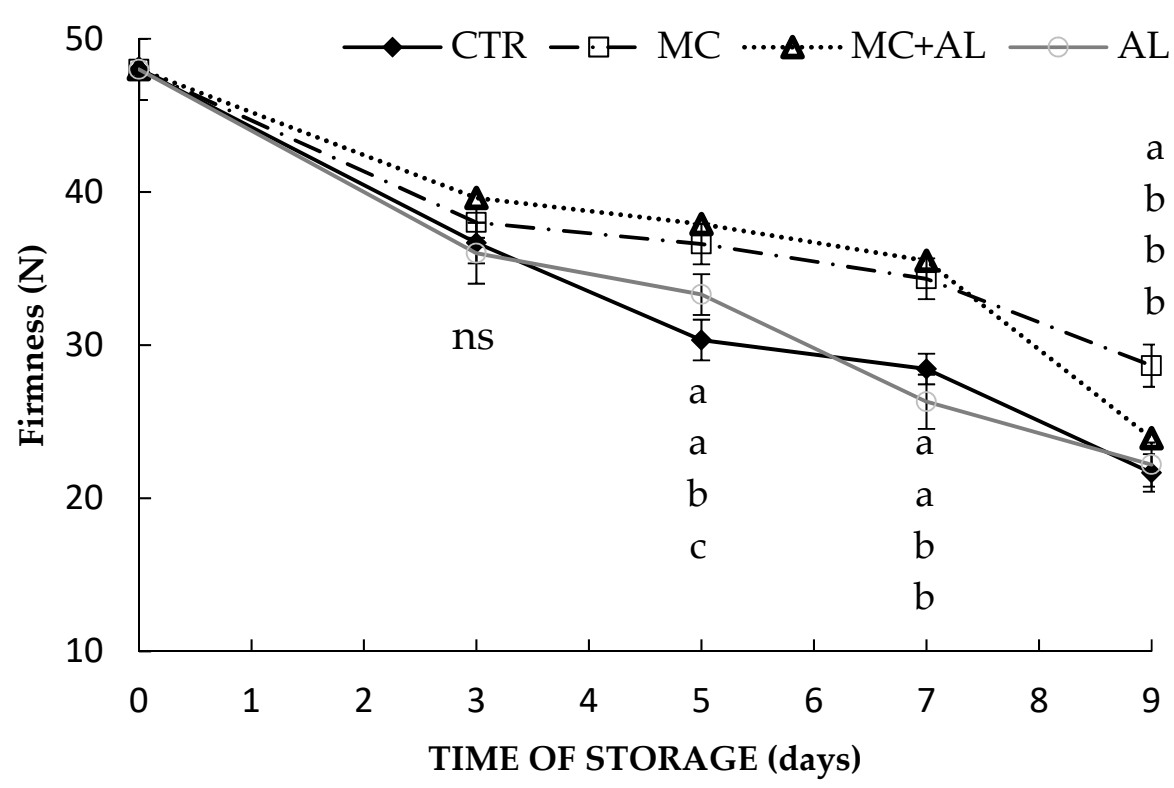

MC+AL: A B B B C

MC: A B C C D

AL: A B B C D

CTR: A B C C D

Figure 2. Firmness of fruit slices of Actinidia deliciosa (Liang, Ferguson) coated with O. ficus-indica (OFI) mucilage (MC), or mucilage + A arborescens $(\mathrm{MC}+\mathrm{AL})$ or $A$. arborescens (AL) not treated (CTR), just after being coated ( 0 ) and at $3,5,7,9$ days of storage at $5{ }^{\circ} \mathrm{C}$. Different lowercase letters indicate significant differences between treatments at each sampling date. Different capital letters indicate significant differences between sampling date for the same treatment. Tukeys' significant test was applied at $p \leq 0.05$. Data are means \pm S.E. $(n=3)$.

After $3 \mathrm{~d}$, weight loss was higher in untreated than in $\mathrm{AL}, \mathrm{MC}$, and $\mathrm{MC}+\mathrm{AL}$ kiwifruit slices, while after the cutting of kiwifruit, no significant differences were observed between treatments (Figure 3).

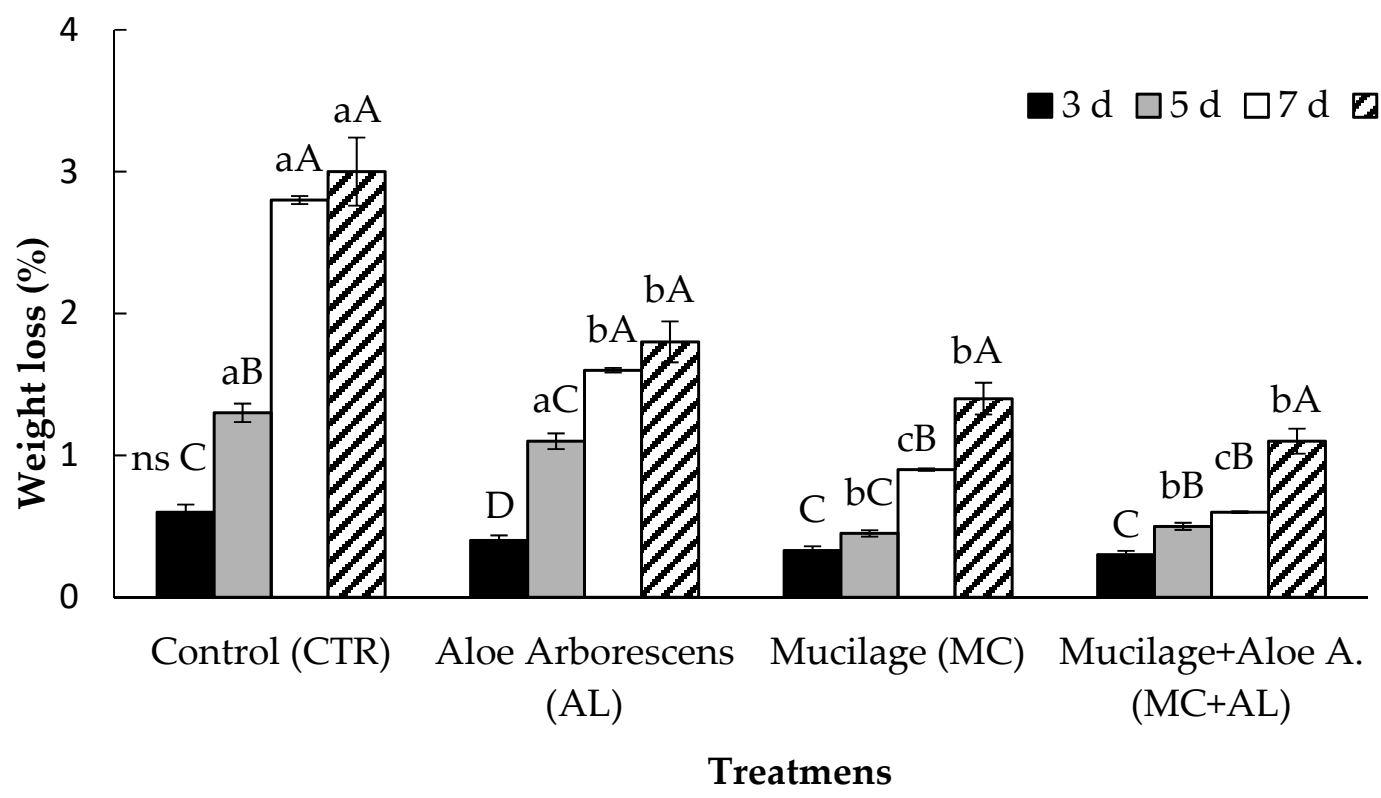

Figure 3. Weight loss (\%) of fruit slices of Actinidia deliciosa (Liang, Ferguson) coated with O. ficusindica (OFI) mucilage (MC), or OFI mucilage (MC), or mucilage $+A$. arborescens $(\mathrm{MC}+\mathrm{AL})$ or $A$. arborescens (AL) not treated (CTR), just after being coated ( 0 ) and at $3,5,7,9$ days of storage at $5{ }^{\circ} \mathrm{C}$. Different lowercase letters indicate significant differences between treatments at each sampling date. Different capital letters indicate significant differences between sampling date for the same treatment. Tukeys' significant test was applied at $p \leq 0.05$. Data are means \pm S.E. $(n=3)$. 
The weight loss of CTR and AL samples slices significantly increased $(p \leq 0.05)$ after $5 \mathrm{~d}$ of storage; at the last sampling time, no weight loss differences occurred between CTR and AL kiwifruit treatments (Figure 3).

In kiwifruit slices coated with $\mathrm{MC}$ or $\mathrm{MC}+\mathrm{AL}$, the weight loss (\%) showed a significant difference $(p \leq 0.05)$ compared to AL treatment and CTR slices. At the 7 th and 9 th day of storage, MC and MC+AL treatments showed a percentage increase of $0.90 \%$ and $0.60 \%$ and $1.40 \%$ and $1.20 \%$, respectively. At the same time points, CTR and AL showed a percentage increase of $2.8 \%$ and $3.0 \%$ and $1.60 \%$ and $1.80 \%$, respectively. In our work, we used the hydrophilic character of the OFI mucilage coating as a barrier to water transfer, retarding dehydration and, therefore, prolonging the firmness during fruit shelf life, while the use of aloe coating at $2 \%$ did not show effects on water loss fruit. There is also evidence for strong covalent interactions between pectin populations and cellulose [36,37]. The addition of $A$. arborescens ( $2 \%$ ) to mucilage solution contributed to a significant effect on total pectin (Figure 4 ) on the 3th day of storage, but not during storage, compared to the MC treatment.

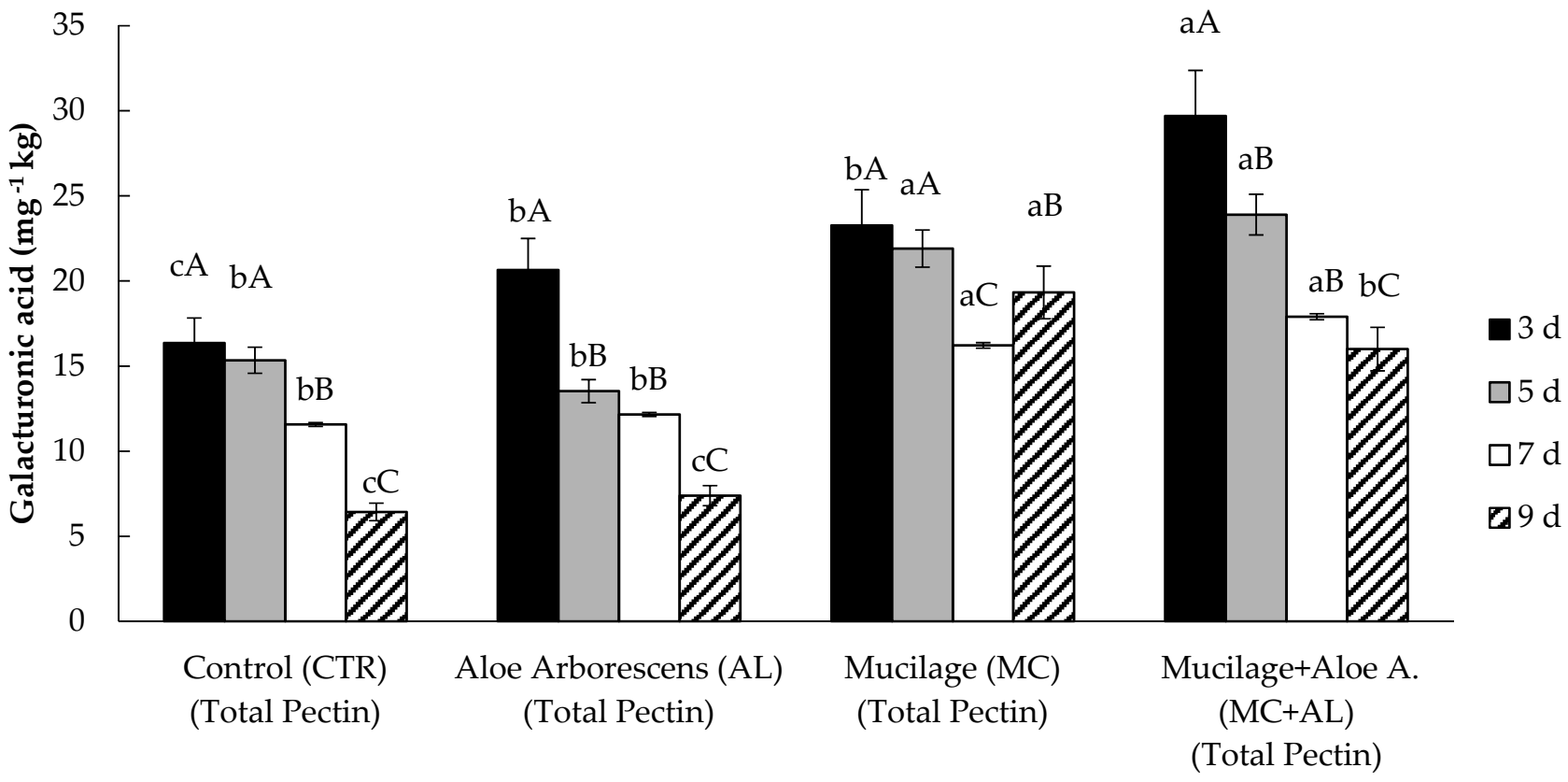

Treatmens

Figure 4. Total pectin (TP) of fruit slices of Actinidia deliciosa (Liang, Ferguson) coated with O. ficusindica (OFI) mucilage (MC), or mucilage + A. arborescens $(\mathrm{MC}+\mathrm{AL})$, or $A$. arborescens $(\mathrm{AL})$ not treated (CTR), just after being coated $(0)$ and at $3,5,7,9$ days of storage at $5{ }^{\circ} \mathrm{C}$. Different lowercase letters indicate significant differences between treatments at each sampling date. Different capital letters indicate significant differences between sampling date for the same treatment. Tukeys' significant test was applied at $p \leq 0.05$. Data are means \pm S.E. $(n=3)$.

Pectin exists in the primary cell wall and the middle layer, which contribute to enhance the adhesion between cells and the mechanical strength of cells [38]. Kiwifruit slices coated with $\mathrm{MC}+\mathrm{AL}$ and $\mathrm{MC}$ showed higher total pectin content than CTR and AL treatments for up to $9 \mathrm{~d}$ of storage (Figure 4). The pectin trends (Figures 4 and 5) influence the loss of firmness (Figure 2) of kiwifruit during storage, as reported by Allegra et al. [14]. Indeed, after cutting, the solubilization and depolymerization of the middle lamella of fruits might contribute to cell wall loosening and disaggregation [39]. During fruit storage, the middle lamella and primary cell wall structures were disassembled; meanwhile, pectin side chains depolymerized due to enzyme effects. These changes led to the loss of firmness, softening of fruit, and an increase of fruit postharvest decay, and decreased the quality of fresh fruit [40]. Therefore, the addition of OFI mucilage + A. Arborescens could significantly interfere with the assembly of structures by reducing the loss of cellular turgidity during 
storage. Indeed, lack of membrane integrity allows the leakage of cellular osmotic solutes into the apoplastic space, which then results in water movements and turgor loss.

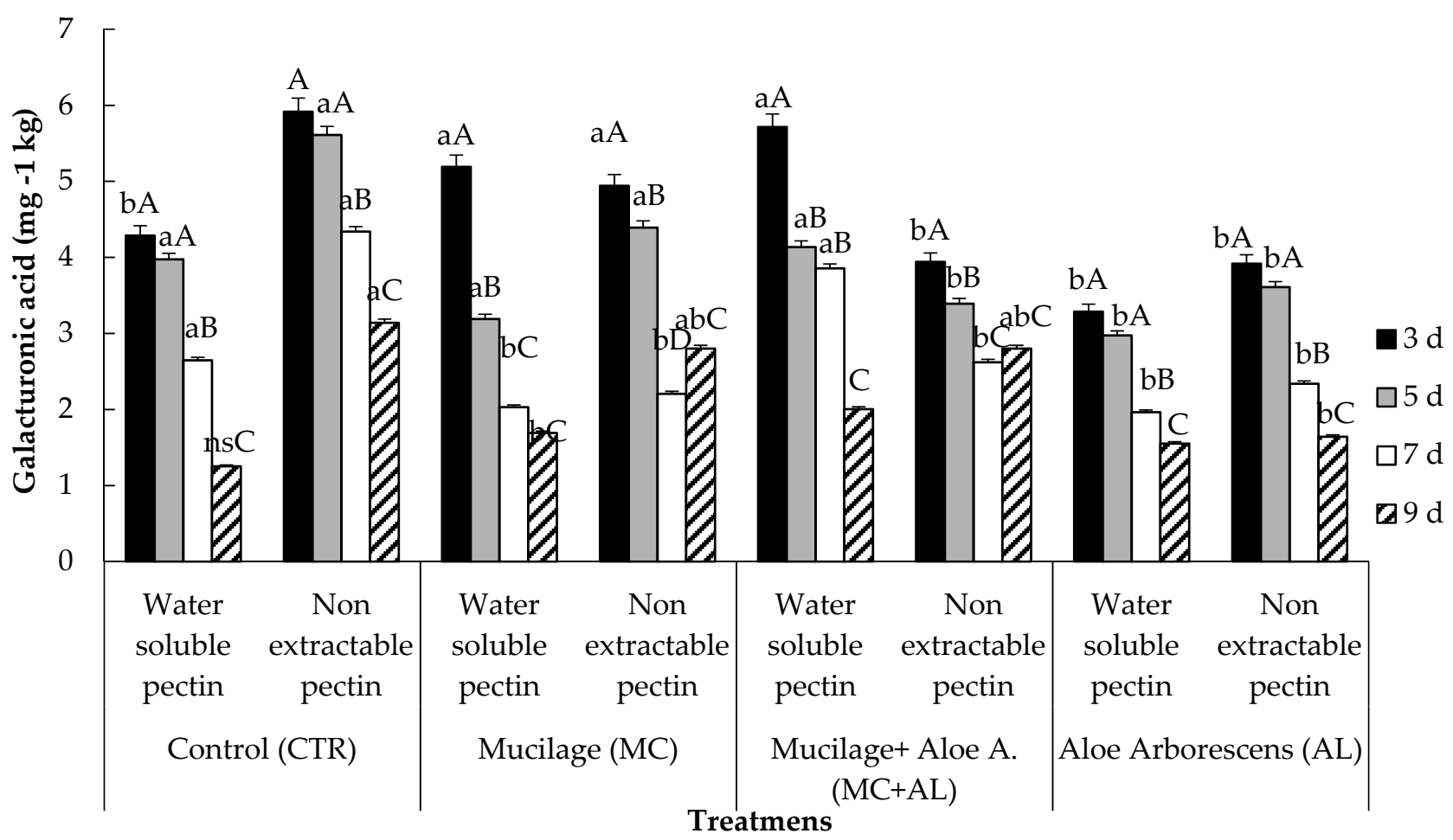

Figure 5. Water soluble pectin (WSP) and non-extractable pectin (NXP) of fruit slices of Actinidia deliciosa (Liang, Ferguson) coated with O. ficus-indica (OFI) mucilage + glycerol (MC), or OFI mucilage (MC), or mucilage $+A$. arborescens $(\mathrm{MC}+\mathrm{AL})$, or $A$. arborescens $(\mathrm{AL})$ not treated (CTR), just after being coated (0) and at $3,5,7,12$ days of storage at $5{ }^{\circ} \mathrm{C}$. Different lowercase letters indicate significant differences between treatments at each sampling date. Different capital letters indicate significant differences between sampling date for the same treatment. Tukeys' significant test was applied at $p \leq 0.05$. Data are means \pm S.E. $(n=3)$.

Soluble pectin content in MC+AL and MC treatments showed a significant difference after cutting compared to CTR and AL treatment. At the 7th day of storage, kiwifruit coated with $\mathrm{MC}+\mathrm{AL}$ showed a higher value than other treatments, but at the 9 th day the values from the same treatment showed a reduction of $47.9 \%$ of soluble pectin content. Non-extractable pectin (Figure 5) significantly decreased in CTR and AL treatments during storage, while $\mathrm{MC}+\mathrm{AL}$ and $\mathrm{MC}$ treatments after $7 \mathrm{~d}$ increased by 27.1 and $6.2 \%$, respectively.

Similar results have been reported from Allegra e al. [14] on kiwifruit coated by mucilage extracted of Opuntia ficus-indica. Our results showed that the OFI effect influences the increase of pectin content during storage; on the contrary, when aloe coating has been used, a decrease of the pectin content is observed. In other works, A. vera and mucilage coating proved to be effective in reducing pectin depolymerization [3,26], while A. arborescens coating proved to reduce firmness loss in peach fruit during cold storage [16].

\subsection{Head Spaces Gas Composition}

Surface coatings can increase a fruit's skin resistance to gas diffusion, modify its internal atmosphere composition, and depress its respiration rate. In fresh fruit, the effect of covering the cuticle and blocking pores were important for resistance to water vapor diffusion [41]. However, the use of cover on skin could change internal atmosphere, respiration, and transpiration rates. This could be important in fresh-cut fruit because the use of coating substitute the removal of cuticle and pores that regulate changes of oxygen and carbon dioxide. In our work, after cutting and packaging in passive atmosphere, 
kiwifruit showed a progressive significant increase of $\mathrm{CO}_{2}$ and a significant decrease in $\mathrm{O}_{2}$. The $\mathrm{O}_{2}(\mathrm{Kpa})$ content inside packages showed significant differences between samples coated with MC and MC+AL compared to CTR and AL treatment after $3 \mathrm{~d}$ of storage. Untreated slices showed lower values than the $\mathrm{MC}+\mathrm{AL}, \mathrm{AL}$, and $\mathrm{MC}$ samples (Figure 6) after 5 and 7 days. An increase of $\mathrm{CO}_{2}$ production was observed after cutting in all sample coated and uncoated, but MC treatment showed the lowest values between $\mathrm{MC}+\mathrm{AL}, \mathrm{AL}$ treatments and CTR. At the 5th day of storage no significant difference occurred between all kiwifruit samples, while at the 7th day kiwifruit coated with MC+AL and CTR showed a significant difference compared to $\mathrm{MC}$ and $\mathrm{AL}$ treatments. After $7 \mathrm{~d}$ all samples showed $\mathrm{CO}_{2}$ production $(<15.8 \mathrm{Kpa})$. Our results showed that kiwi slices treated with the $\mathrm{MC}+\mathrm{AL}$ solution had a lower $\mathrm{CO}_{2}$ concentration in bags until $7 \mathrm{~d}$. A similar result was observed by Benitez et al. [3] on kiwi slices coated with $A$. vera combined with package under passive atmosphere and low temperature $\left(2 \pm 1^{\circ} \mathrm{C}\right)$. The reduction of respiration was observed also in coated sweet cherry [42] and in table grapes [43].

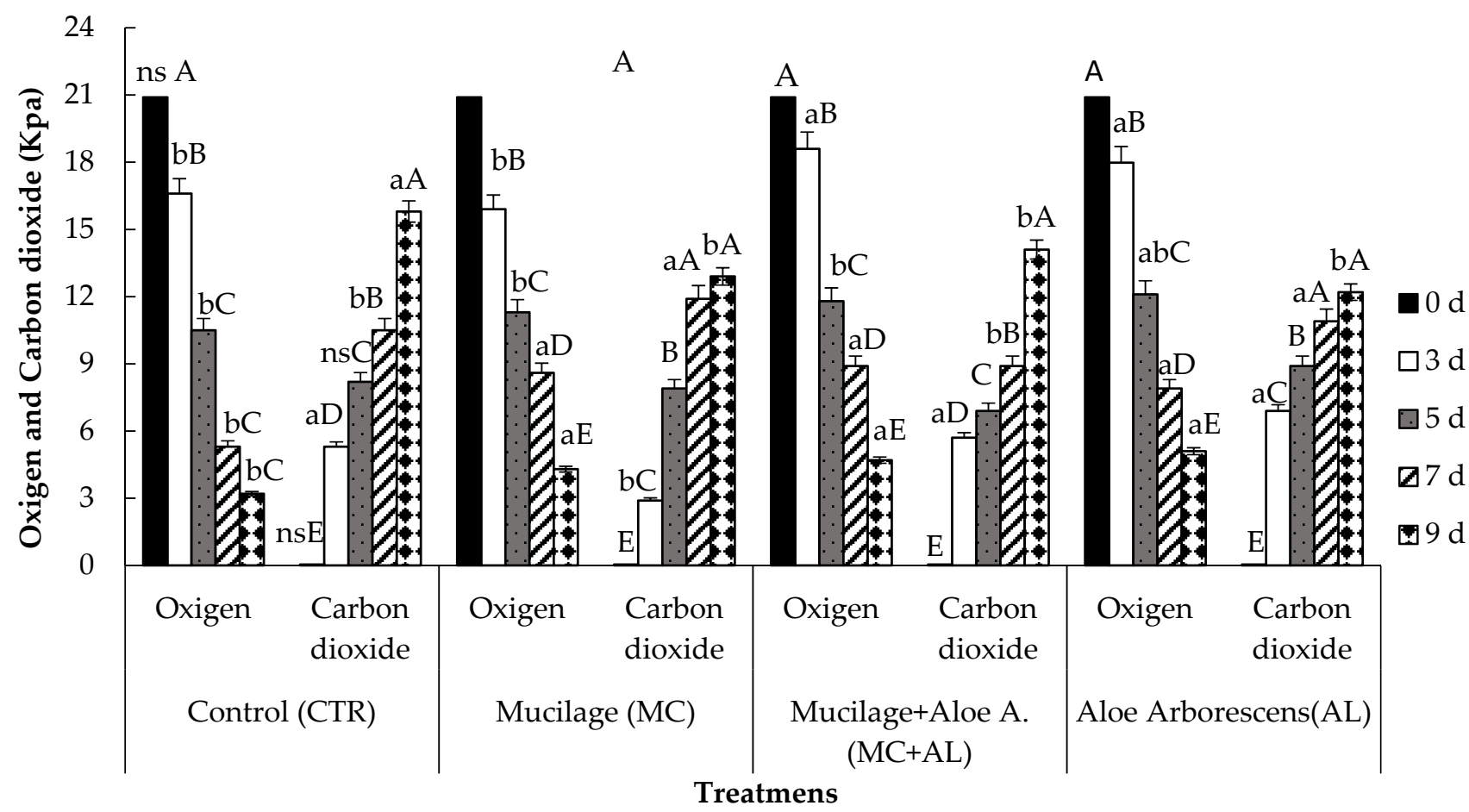

Figure 6. Oxygen and Carbon dioxide content $(\mathrm{kPa})$ inside packages with fruit slices of Actinidia deliciosa (Liang, Ferguson) coated with O. ficus-indica (OFI) mucilage (MC), or mucilage $+A$. arborescens $(\mathrm{MC}+\mathrm{AL})$, or $A$. arborescens (AL) not treated (CTR), just after being coated ( 0 ) and at 3, 5, 7, 9 days of storage at $5{ }^{\circ} \mathrm{C}$ Different lowercase letters indicate significant differences between treatments at each sampling date. Different capital letters indicate significant differences between sampling date for the same treatment and parameter (Oxigen, carbon dioxide). Tukeys' significant test was applied at $p \leq 0.05$. Data are means \pm S.E. $(n=3)$.

\subsection{Microbiological Analysis}

Aloe gel is made of a wide range of constituents that are mainly responsible for inhibiting the the growth of both Gram-positive and Gram-negative bacteria such as Bacillus cereus, Salmonella typhimurium, Escherichia coli, and Klebsialla pneumonia [44]. Allegra et al. [14] showed that the use of OFI mucilage on kiwifruit slices does not inhibit significantly the grown of yeast and bacteria; on the contrary, $A$. arborescens coating reduced the microbial spoilage of kiwifruit during $7 \mathrm{~d}$ of storage [3]. The loads of aerobic mesophilic bacteria, pseudomonas, and yeast detected on the different samples collected during the experimentations are reported in Table 3. The microbiological analyses of solutions of different coatings $(\mathrm{MC}, \mathrm{MC}+\mathrm{AL}$, and $\mathrm{AL}$ ) did not evidence the presence of any of the microbial 
groups observed. The groups of aerobic mesophilic bacteria were detected after cutting and at the 3 rd day of storage in all treatments with low concentration $\left(<2 \mathrm{Log} \mathrm{CFU} \mathrm{g}^{-1}\right)$. No differences occurred between MC+AL coated slices and AL at the 5th and 7th $d$ of storage. At the same times, the values of CTR and AL showed an increase in this population, with a load of 3.2 and 3.6, and 4.2 and $5.4 \mathrm{Log} \mathrm{CFU}^{-1}$, respectively. The presence of pseudomonads were detected after $7 \mathrm{~d}$ of storage (Table 5).

Table 5. Total mesophilic, Pseudomonads, and yeast content $\left(\mathrm{Log}_{\mathrm{CFU} \mathrm{g}}{ }^{-1}\right)$ in fruit slices of Actinidia deliciosa (Liang. Ferguson) coated with O. ficus-indica (OFI) mucilage (MC), or mucilage $+A$. arborescens $\mathrm{MC}+\mathrm{AL}$, or $A$. arborescens (AL) not treated (CTR), just after being coated (0) and at 3, 5, 7, 9 days of storage at $5{ }^{\circ} \mathrm{C}$. Different lowercase letters indicate significant differences between treatments at each sampling date. Different capital letters indicate significant differences between sampling date for the same treatment. Tukeys' significant test was applied at $p \leq 0.05$. Data are means \pm S.E. $(n=3)$.

\begin{tabular}{|c|c|c|c|c|c|c|c|c|c|c|c|c|}
\hline \multirow{3}{*}{$\begin{array}{l}\text { Time of } \\
\text { Storage } \\
\text { (Days) }\end{array}$} & \multicolumn{12}{|c|}{ Treatments } \\
\hline & \multicolumn{4}{|c|}{$\begin{array}{c}\text { Aerobic Mesophile Bacteria } \\
\left(\operatorname{Log~CFU~g}^{-1}\right)\end{array}$} & \multicolumn{4}{|c|}{$\begin{array}{l}\text { Pseudomonads } \\
\left(\log \text { CFU g }{ }^{-1}\right)\end{array}$} & \multicolumn{4}{|c|}{$\begin{array}{l}\text { Yeast Content } \\
\left(\operatorname{Log~CFU~g~}^{-1}\right)\end{array}$} \\
\hline & CTR & MC & $\mathrm{MC}+\mathrm{AL}$ & $\mathbf{A L}$ & CTR & MC & $\mathrm{MC}+\mathrm{AL}$ & $\mathbf{A L}$ & CTR & MC & $\mathrm{MC}+\mathrm{AL}$ & $\mathbf{A L}$ \\
\hline 0 days & $0 \mathrm{nsD}$ & $0 \mathrm{D}$ & $0 \mathrm{~B}$ & $0 \mathrm{~B}$ & $0 \mathrm{nsC}$ & $0 \mathrm{C}$ & $0 \mathrm{C}$ & $0 \mathrm{C}$ & $0 \mathrm{nsC}$ & $0 \mathrm{D}$ & $0 \mathrm{C}$ & $0 \mathrm{~b}$ \\
\hline 3 days & $0.9 \mathrm{aC}$ & $1.1 \mathrm{aC}$ & $0 \mathrm{bB}$ & $0 \mathrm{bB}$ & $0 \mathrm{nsC}$ & $0 \mathrm{C}$ & $0 \mathrm{C}$ & $0 \mathrm{C}$ & $0 \mathrm{nsC}$ & $0 \mathrm{D}$ & $0 \mathrm{C}$ & $0 \mathrm{~B}$ \\
\hline 5 days & $1 \mathrm{bC}$ & $2 \mathrm{aB}$ & $0 \mathrm{cB}$ & $0 \mathrm{cB}$ & $0 \mathrm{nsC}$ & $0 \mathrm{C}$ & $0 \mathrm{C}$ & $0 \mathrm{C}$ & $0 \mathrm{cC}$ & $2.9 \mathrm{aC}$ & $0.1 \mathrm{bC}$ & $0 \mathrm{cB}$ \\
\hline 7 days & $1.9 \mathrm{bB}$ & $4.3 \mathrm{aA}$ & $0 \mathrm{cB}$ & $0 \mathrm{cB}$ & $2 \mathrm{bB}$ & $3.5 \mathrm{aB}$ & $1 \mathrm{cB}$ & $0.5 \mathrm{cB}$ & $1 \mathrm{bB}$ & $3.3 \mathrm{aB}$ & $1.1 \mathrm{bB}$ & $0 \mathrm{cB}$ \\
\hline 9 days & $3.3 \mathrm{bA}$ & $5.4 \mathrm{aA}$ & $1 \mathrm{cA}$ & $1 \mathrm{cA}$ & $4.5 \mathrm{aA}$ & $5 \mathrm{aA}$ & $1.5 \mathrm{bA}$ & $1 \mathrm{bA}$ & $2 \mathrm{bA}$ & $4 \mathrm{aA}$ & $1.5 \mathrm{bA}$ & $1.3 \mathrm{cA}$ \\
\hline
\end{tabular}

Differences among treatments appeared after 7 and $9 \mathrm{~d}$ of storage when CTR, MC, and AL treatments were characterized by different concentrations of pseudomonads. No differences occurred between MC coated slices and CTR after $5 \mathrm{~d}$ of storage. Pseudomonad's content (Table 5) did not show significant differences in all samples during $5 \mathrm{~d}$ of storage, while a significant increase in this population occurred in $\mathrm{MC}$, showing a load of 1.77 $\log$ CFU g ${ }^{-1}$ after $7 \mathrm{~d}$. A similar trend was also observed for yeasts. In this case, the highest increase in concentration was registered on $\mathrm{MC}$ and $\mathrm{MC}+\mathrm{AL}$ kiwifruit slices after 5 and 7 days. The addition of $A$. arborescens to the mucilage coating solution significantly reduced the aerobic mesophilic bacteria, pseudomonads, and yeast contents on kiwifruit slices during storage time. However, the cell densities of pseudomonads and yeasts were not able to determine a microbial decay of the sliced kiwifruits (Table 5).

\section{Conclusions}

This work reported the efficiency of A. arborescens + Opuntia ficus-indica coating on fresh-cut kiwi fruit. A. arborescens + Opuntia ficus-indica mucilage coating showed significant benefits in the postharvest quality of fresh-cut 'Hayward' kiwifruit, retarding fruit ripening and maintaining visual score and firmness. Moreover, it maintained the titratable acidity and total soluble solids and reduced the weight loss, in addition avoiding the microbial activity. A arborescens + Opuntia ficus-indica coating mucilage allowed a gain of three days for commercial shelf life and 7 days for visual score parameter, as compared to the uncoated fresh-cut fruit.

Author Contributions: Conceptualization, G.S., A.A. and P.I.; methodology, G.S. and A.A.; validation, V.F., A.A. and G.S.; formal analysis, G.S., A.A. and R.P.; investigation, A.A., V.F. and G.S.; resources, A.A., V.F. and G.S.; software, A.A., R.P. and G.S.; data curation, V.F., A.A. and G.S.; writing-original draft preparation, A.A., P.I. and G.S.; writing-review and editing, G.S., A.A. and P.I.; visualization G.S. and A.A.; supervision, A.A., G.S. and P.I. All authors have read and agreed to the published version of the manuscript.

Funding: This research was funded by FFR2021 Giuseppe Sortino.

Institutional Review Board Statement: Not applicable. 


\section{Informed Consent Statement: Not applicable.}

Data Availability Statement: All data generated or analyzed during this study are included in this published article.

Conflicts of Interest: The authors declare no conflict of interest.

\section{References}

1. Schroder, R.; Atkinson, R.G. Kiwifruit cell walls: Towards an understanding of softening? N. Z. J. For. Sci. 2006, 36, 112-129.

2. Karakurt, Y.; Huber, D.J. Activities of several membrane and cell-wall hydrolases, ethylene biosynthetic enzymes, and cell wall polyuronide degradation during low-temperature storage of intact and fresh-cut papaya (Carica papaya) fruit. Postharvest Biol. Technol. 2003, 28, 219-229. [CrossRef]

3. Benitez, S.; Achaerandio, I.; Sepulcre, F.; Pujola, M.A. Aloe vera based edible coatings improve the quality of minimally processed 'Hayward' kiwifruit. Postharv. Biol. Technol. 2013, 81, 29-36. [CrossRef]

4. Mastromatteo, M.; Mastromatteo, M.; Conte, A.; Del Nobile, M.A. Combined effect of active coating and MAP to prolong the shelf life of minimally processed kiwifruit (Actinidia deliciosa cv. Hayward). Food Res. Int. 2011, 44, 1224-1230. [CrossRef]

5. Passafiume, R.; Gaglio, R.; Sortino, G.; Farina, V. Effect of Three Different A. vera Gel-Based Edible coatings on the Quality of Fresh-Cut "Hayward" Kiwifruits. Foods 2020, 9, 939. [CrossRef]

6. Del Valle, V.; Hernández-Muñoz, P.; Guarda, A.; Galotto, M.J. Development of a cactus-mucilage edible coating (Opuntia ficus indica) and its application to extend strawberry (Fragaria ananassa) shelf life. Food Chem. 2005, 91, 751-756. [CrossRef]

7. Passafiume, R.; Perrone, A.; Sortino, G.; Gianguzzi, G.; Saletta, F.; Gentile, C.; Farina, V. Chemical-physical characteristics, polyphenolic content and total antioxidant activity of three Italian-grown pomegranate cultivars. NFS J. 2019, 16, 9-14. [CrossRef]

8. Lai, Q.; Wang, H.; Guo, X.; Abbasi, A.M.; Wang, T.; Li, T.; Liu, R.H. Comparison of phytochemical profiles, antioxidant and cellular antioxidant activities of seven cultivars of Aloe. Int. J. Food Sci. Technol. 2016, 51, 1489-1494. [CrossRef]

9. Zapata, P.J.; Navarro, F.D.; Guillén, S.; Castillo, D.; Martínez-Romero, D.; Valero, D.; Serrano, M. Characterisation of gels from different Aloe spp. as antifungal treatment: Potential crops for industrial applications. Ind. Crops Prod. 2013, 42, 223-230. [CrossRef]

10. Allegra, A.; Sortino, G.; Inglese, P.; Settanni, L.; Todaro, A.; Gallotta, A. The effectiveness of Opuntia ficus-indica mucilage edible coating on postharvest maintenance of 'Dottato' fig (Ficus carica L.) fruit. Food Packag. Shelf Life 2017, 12, 135-141. [CrossRef]

11. Trachtenberg, S.; Mayer, A.M. Composition and Properties of Opuntia Ficus-indica mucilage. Phytochemistry 1981, 20, 2665-2668. [CrossRef]

12. Sáenz, C.; Montoya, L.C. Nopalitos: Nueva hortaliza para Chile. El Campesino 1999, 130, 4-7.

13. Medina-Torres, L.; Brito-De La Fuente, E.; Torrestiana-Sanchez, B.; Katthain, R. Rheological properties of the mucilage gum (Opuntia ficus indica). Food Hydrocoll. 2000, 14, 417-424. [CrossRef]

14. Allegra, A.; Inglese, P.; Sortino, G.; Settanni, L.; Todaro, A.; Liguori, G. The influence of Opuntia ficus-indica mucilage edible coating on the quality of 'Hayward'kiwifruit slices. Postharvest Biol. Technol. 2016, 120, 45-51. [CrossRef]

15. Sáenz, C.; Vásquez, M.; Trumper, S.; Fluxá, C. Extractión y Composición Química del Mucílago de Tuna (Opuntia ficus indica). In Proceedings of the II Congreso Internacional de Tuna y Cochinilla, Santiago, Chile, 22-25 September 1992; pp. 93-96.

16. Sortino, G.; Saletta, F.; Puccio, S.; Scuderi, D.; Allegra, A.; Inglese, P.; Farina, V. Extending the shelf life of white peach fruit with 1-methylcyclopropene and A. arborescens edible coating. Agriculture 2019, 10, 151. [CrossRef]

17. Chironi, S.; Sortino, G.; Allegra, A.; Saletta, F.; Caviglia, V.; Ingrassia, M. Consumer assessment on sensory attributes of fresh table grapes cv 'Italia' and 'Red globe' after long cold storage treatment. Chem. Eng. Trans. 2017, 58, 421-426.

18. Rouse, A.H.; Atkins, C.D. Pectinesterase and pectin in commercial citrus juices as determined by methods used at the Citrus Experiment Station. Calif. Agric. Exp. Stn. Bull. 1955, 570, 1-9.

19. Rouse, A.H.; Atkins, C.D. Heat inactivation of pectinesterase in citrus juices. Food Technol. 1952, 6, $291-294$.

20. Ahmed, A.E.R.; Labavitch, J.M. A simplified method for accurate determination of cell wall uronide content. J. Food Biochem. 1978, 1, 361-365. [CrossRef]

21. Kintner, P.K.; Buren, J.P. Carbohydrate Interference and Its Correction in Pectin Analysis Using the m-Hydroxydiphenyl Method. J. Food Sci. 1982, 47, 756-759. [CrossRef]

22. Yu, L.; Reitmeier, C.A.; Love, M.H. Strawberry texture and pectin content as affected by electron beam irradiation. J. Food Sci. 1996, 61, 844-846. [CrossRef]

23. Xu, F.; Liu, S.; Liu, Y.; Xu, J.; Liu, T.; Dong, S. Effectiveness of lysozyme coatings and 1-MCP treatments on storage and preservation of kiwifruit. Food Chem. 2019, 288, 201-207. [CrossRef] [PubMed]

24. Jordan, R.B.; Walton, E.F.; Klages, K.U.; Seelye, R.J. Postharvest fruit density as an indicator of dry matter and ripened soluble solids of kiwifruit. Postharvest Biol. Technol. 2000, 20, 163-173. [CrossRef]

25. Sicari, V.; Loizzo, M.R.; Pellicanò, T.M.; Giuffrè, A.M.; Poiana, M. Evaluation of A. arborescens gel as new coating to maintain the organoleptic and functional properties of strawberry (Fragaria $\times$ ananassa cv. Cadonga) fruits. Int. J. Food Sci. Technol. 2019, 55, 861-870. [CrossRef] 
26. Famiani, F.; Battistelli, A.; Moscatello, S.; Cruz-Castillo, J.G.; Walker, R.P. The organic acids that are accumulated in the flesh of fruits: Occurrence, metabolism and factors affecting their contents-A review. Rev. Chapingo Ser. Hortic. 2015, 21, 97-128. [CrossRef]

27. Allegra, A.; Gallotta, A.; Carimi, F.; Mercati, F.; Inglese, P.; Martinelli, F. Metabolic profiling and post-harvest behavior of "Dottato" fig (Ficus carica L.) fruit covered with an edible coating from O. ficus-indica. Front. Plant Sci. 2018, 9, 1321. [CrossRef]

28. Soliva-Fortuny, R.; Martín-Belloso, O. Fresh-cut fruits: Apples and pears. In Controlled and Modified Atmospheres for Fresh and Fresh-Cut Produce; Gil, M.I., Beaudry, R., Eds.; Elsevier Inc.: London, UK, 2020; pp. 487-494.

29. Wang, D.; Yeats, T.H.; Uluisik, S.; Rose, J.K.; Seymour, G.B. Fruit softening: Revisiting the role of pectin. Trends Plant Sci. 2018, 23, 302-310. [CrossRef]

30. Brummell, D.A.; Cin, V.D.; Crisosto, C.H.; Labavitch, J.M. Cell wall metabolism during maturation, ripening and senescence of peach fruit. J. Exp. Bot. 2008, 55, 2029-2039. [CrossRef]

31. Hamman, J.H. Composition and applications of A. vera leaf gel. Molecules 2008, 13, 1599-1616. [CrossRef]

32. Espino-Díaz, M.; De Jesús Ornelas-Paz, J.; Martínez-Téllez, M.A.; Santillán, C.; Barbosa-Cánovas, G.V.; Zamudio-Flores, P.B.; Olivas, G.I. Development and characterization of edible films based on mucilage of Opuntia ficus-Indica (1.). J. Food Sci. 2010, 75, E347-E352. [CrossRef]

33. Dave, R.K.; Ramana Rao, T.V.; Nandane, A.S. Improvement of post-harvest quality of pear fruit with optimized composite edible coating formulations. J. Food Sci. Technol. 2017, 54, 3917-3927. [CrossRef] [PubMed]

34. Gol, N.B.; Patel, P.R.; Rao, T.R. Improvement of quality and shelf-life of strawberries with edible coatings enriched with chitosan. Postharvest Biol. Technol. 2013, 85, 185-195. [CrossRef]

35. Pérez-Gago, M.B.; Rojas, C.; Del Río, M.A. Effect of lipid type and amount of edible hydroxypropyl methylcellulose-lipid composite coatings used to protect postharvest quality of Mandarins cv. Fortune. J. Food Sci. 2002, 67, 2903-2910. [CrossRef]

36. Park, Y.B.; Cosgrove, D.J. Changes in cell wall biomechanical properties in the xyloglucan-deficient xxt1/xxt2 mutant of Arabidopsis. Plant Physiol. 2012, 158, 465-475. [CrossRef] [PubMed]

37. Broxterman, S.E.; Schols, H.A. Interactions between pectin and cellulose in primary plant cell walls Carbohydrate. Polymers 2018, 192, 263-272.

38. Cybulska, J.; Zdunek, A.; Kozioł, A. The self-assembled network and physiological degradation of pectins in carrot cell walls. Food Hydrocoll. 2015, 43, 41-50. [CrossRef]

39. Billy, L.; Mehinagic, E.; Royer, G.; Renard, C.M.; Arvisenet, G.; Prost, C. Relationship between texture and pectin composition of two apple cultivars during storage. Postharvest Biol. Technol. 2008, 47, 315-324. [CrossRef]

40. Rosli, H.G.; Civello, P.M.; Martínez, G.A. Changes in cell wall composition of three Fragaria $x$ ananassa cultivars with different softening rate during ripening. Plant Physiol. Biochem. 2004, 42, 823-831. [CrossRef]

41. Banks, N.H.; Dadzie, B.K.; Cleland, D.J. Reducing gas exchange of fruits with surface coatings. Postharv. Biol. Technol. 1993, 3 , 269-284. [CrossRef]

42. Martinez-Romero, D.; Alburquerque, N.; Valverde, J.; Guillen, F.; Castillo, S.; Valero, D.; Serrano, M. Postharvest sweet cherry quality and safety maintenance by A. vera treatment: A new edible coating. Postharv. Biol. Technol. 2006, 39, 93-100. [CrossRef]

43. Tripathi, P.; Dubey, N. Exploitation of natural products as an alternative strategy to control postharvest fungal rotting of fruit and vegetables. Postharv. Biol. Technol. 2004, 32, 235-245. [CrossRef]

44. Misir, J.; Brishti, F.H.; Hoque, M.M.A. Aloe vera gel as a novel edible coating for fresh fruits: A review. Am. J. Food Sci. Technol. 2014, 2, 93-97. [CrossRef] 